\title{
Temporal Dynamics of East Texas Caddo Sites with Nine or Fewer Radiocarbon Dates
}

Robert Z. Selden Jr. Heritage Research Center, Stephen F. Austin State University

Follow this and additional works at: https://scholarworks.sfasu.edu/ita

Part of the American Material Culture Commons, Archaeological Anthropology Commons, Environmental Studies Commons, Other American Studies Commons, Other Arts and Humanities Commons, Other History of Art, Architecture, and Archaeology Commons, and the United States History Commons

Tell us how this article helped you.

This Article is brought to you for free and open access by the Center for Regional Heritage Research at SFA ScholarWorks. It has been accepted for inclusion in Index of Texas Archaeology: Open Access Gray Literature from the Lone Star State by an authorized editor of SFA ScholarWorks. For more information, please contact cdsscholarworks@sfasu.edu. 


\section{Temporal Dynamics of East Texas Caddo Sites with Nine or Fewer Radiocarbon}

Dates

\section{Creative Commons License}

\section{(c) (1) \&}

This work is licensed under a Creative Commons Attribution-NonCommercial 4.0 International License 


\title{
Temporal Dynamics of East Texas Caddo Sites with Nine or Fewer Radiocarbon Dates
}

\author{
Robert Z. Selden, Jr.
}

\section{INTRODUCTION}

This article presents the specifics from the date combination process, and the subsequent production of summed probability distributions for radiocarbon $\left({ }^{14} \mathrm{C}\right)$ assays from Caddo sites in East Texas. All ${ }^{14} \mathrm{C}$ dates employed in this effort were collected from research and cultural resource management (CRM) reports and publications, were synthesized, and then recalibrated in version 4.2.2 of OxCal (Bronk Ramsey 2013) using IntCal09 (Reimer et al. 2009) (Perttula and Selden 2011). These data are meant to augment those from previous analyses of radiocarbon samples from East Texas Caddo sites (Selden and Perttula 2013a, 2013b), assisting in refining these ideas further.

\section{METHODS}

The methods employed within this article were initially outlined within a temporal investigation of the Woodland period (Selden 2012), and have been used within a number of more recent publications aimed at delineating temporal trends within the Archaic (Selden 2013b) and Caddo periods (Selden and Perttula 2013a, 2013b), and are not discussed here.

\section{COMBINING THE SAMPLE}

The 55 Caddo sites with nine or fewer ${ }^{14} \mathrm{C}$ dates include the following sites: Alcoa No. 1 (41AN87), Hatchel (41BW3), Cranfill (41BW171), 41BW553, 41CE299, Kah-hah-ko-wha (41CE354), Shelby (41CP71), 41CP88, 41CP316, Knight's Bluff (41CS14), 41CS151, Spike (41DT16), 41DT63, Thomas (41DT80), Doctors Creek (41DT124), 41DT141, Hardin-A (41GG69), 41HE343, Lawson (41HP78), Mound Pond (41HS12), 41HS231, 41HS588, 41HS846, Mackin (41LR39), Ray (41LR135), 41MX5, Chayah (41NA44), Washington Square (41NA49), Foggy Fork (41NA235), Naconiche Creek (41NA236), Miles Boundary (41NA248), Telesco (41NA280), Boyette (41NA285), Hudnall-Pirtle (41RK4), Herman Ballew (41RK222), 41RK557, Holdeman (41RR11), Fasken (41RR14), Roitsch/Sam Kaufman (41RR16), Rowland Clark (41RR77), Redwine (41SM193), Broadway (41SM273), Leaning Rock (41SM325), 41SM404, Tyson (41SY92), 41TT372, Mockingbird (41TT550), James Owens (41TT769), Harroun (41UR10), Kelsey Creek Dam (41UR118), Camp Joy (41UR144), Henry Spencer (41UR315), McKenzie (41WD55), Spoonbill (41WD109), and Taddlock (41WD482). In the following section, the samples are refined through date combination, and the subsequent results (combined dates) replace the original assays in the subsequent analysis of all ${ }^{14} \mathrm{C}$ samples from Caddo sites.

The ${ }^{14} \mathrm{C}$ dates from the Hatchel site serve as an overview of the date combination process (Figure 1), after which all sites with nine or fewer dates are listed in chronological order (Figure 2a-e). While these results clarify much with regard to the temporal position of contributing sites, further work is needed to expound upon this understudied amalgam of chronometric dates. The application of some manner of chronometric hygiene is warranted, and while that will greatly diminish the number of ${ }^{14} \mathrm{C}$ dates from the Caddo period, it should greatly increase the resolution of the current temporal model. 


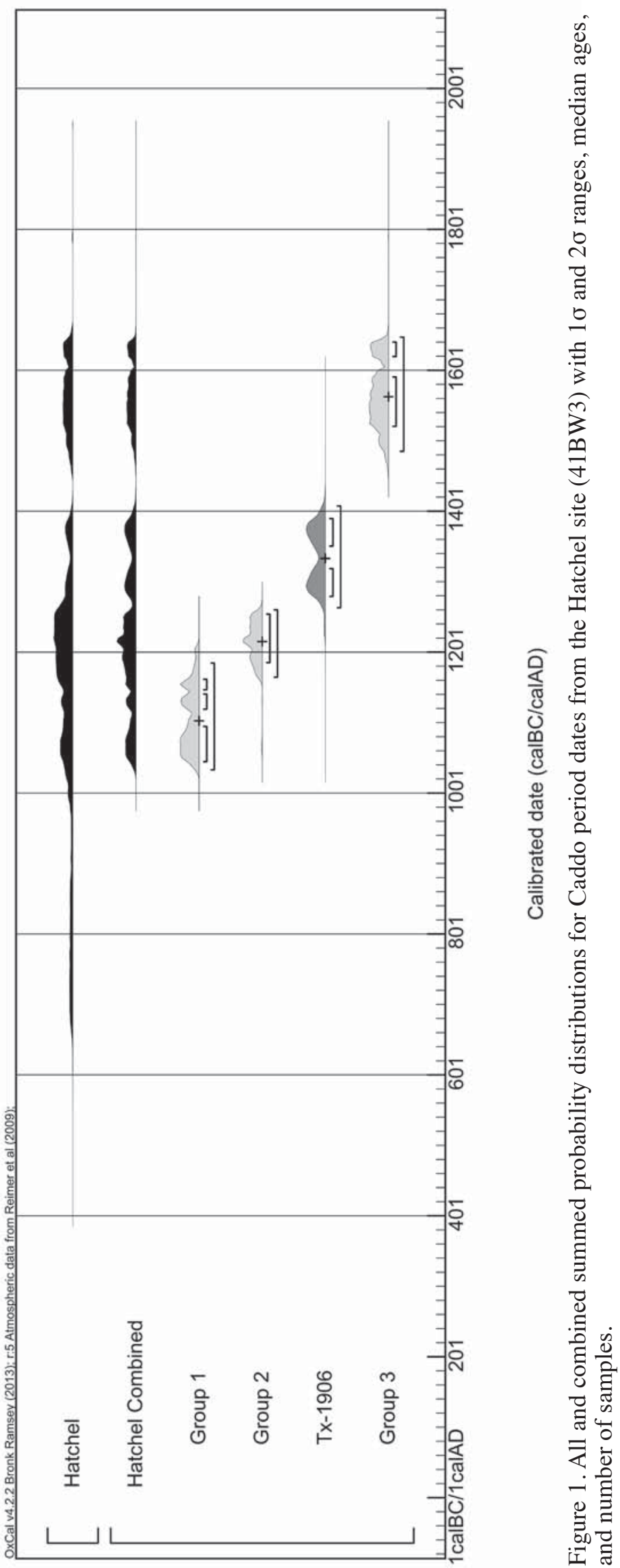




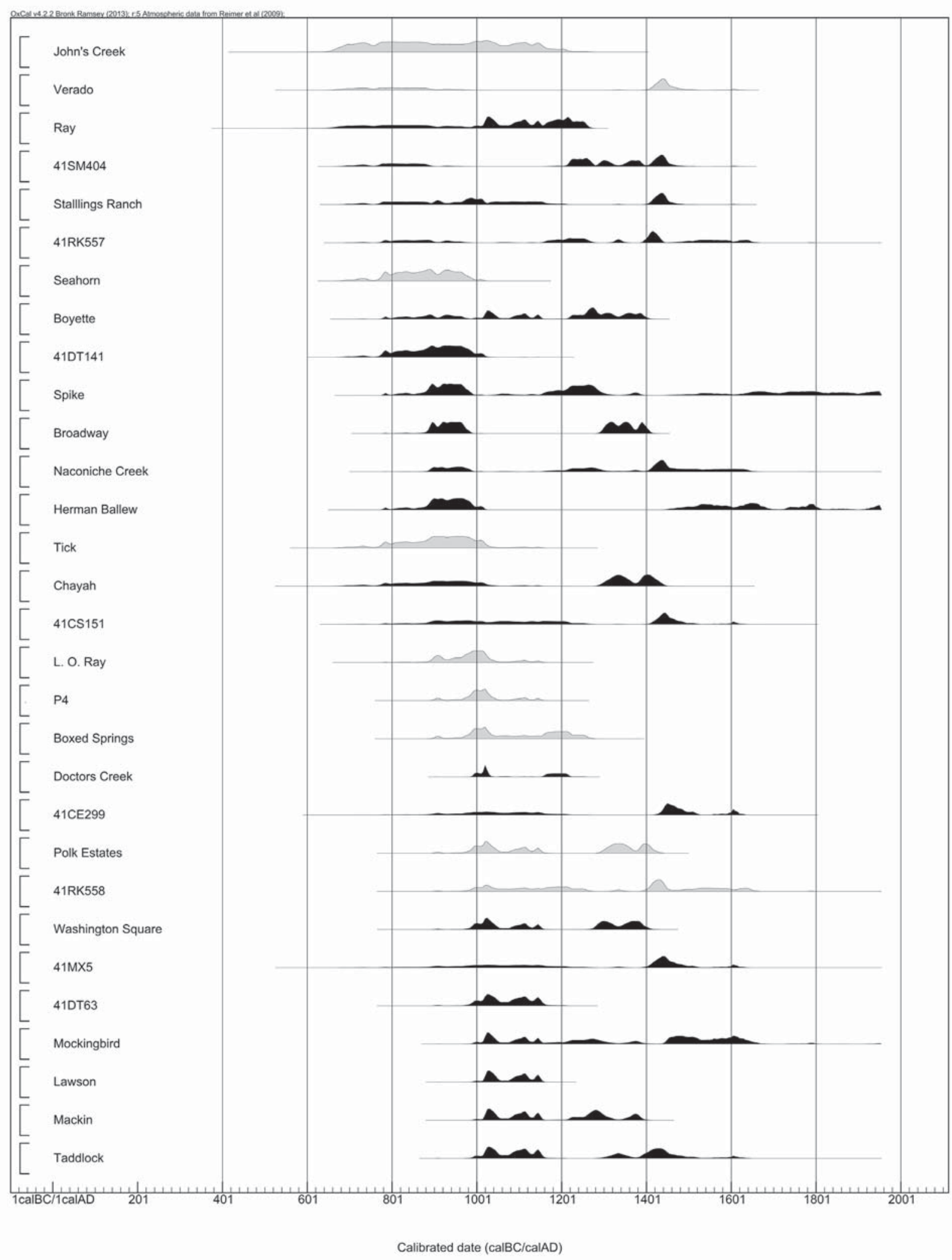

Figure 2a. Site-specific summed probability distributions listed in chronological order. Sites with combined dates appear in black, post-A.D. 800. 


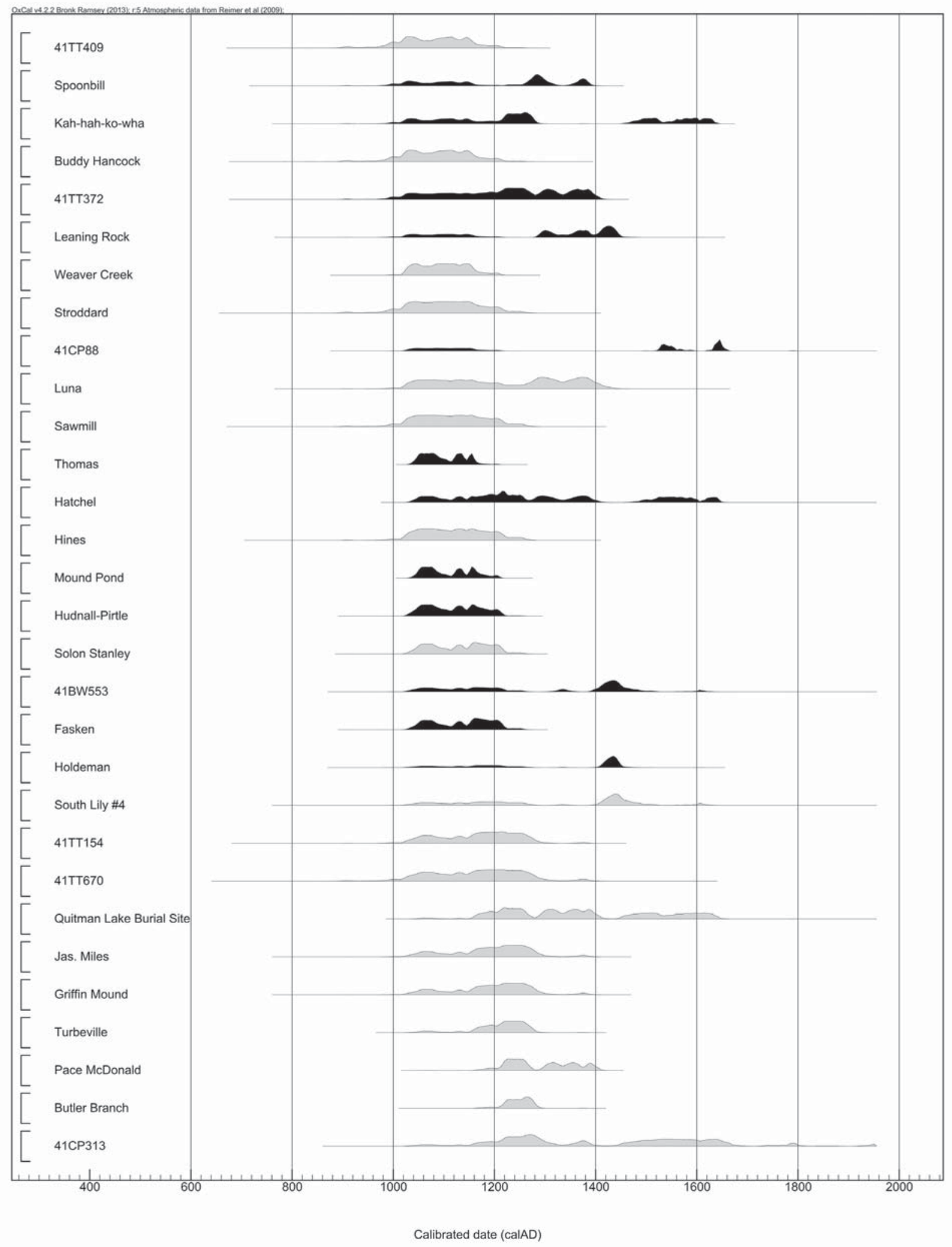

Figure $2 \mathrm{~b}$. Site-specific summed probability distributions listed in chronological order. Sites with combined dates appear in black, post-A.D. 1000. 


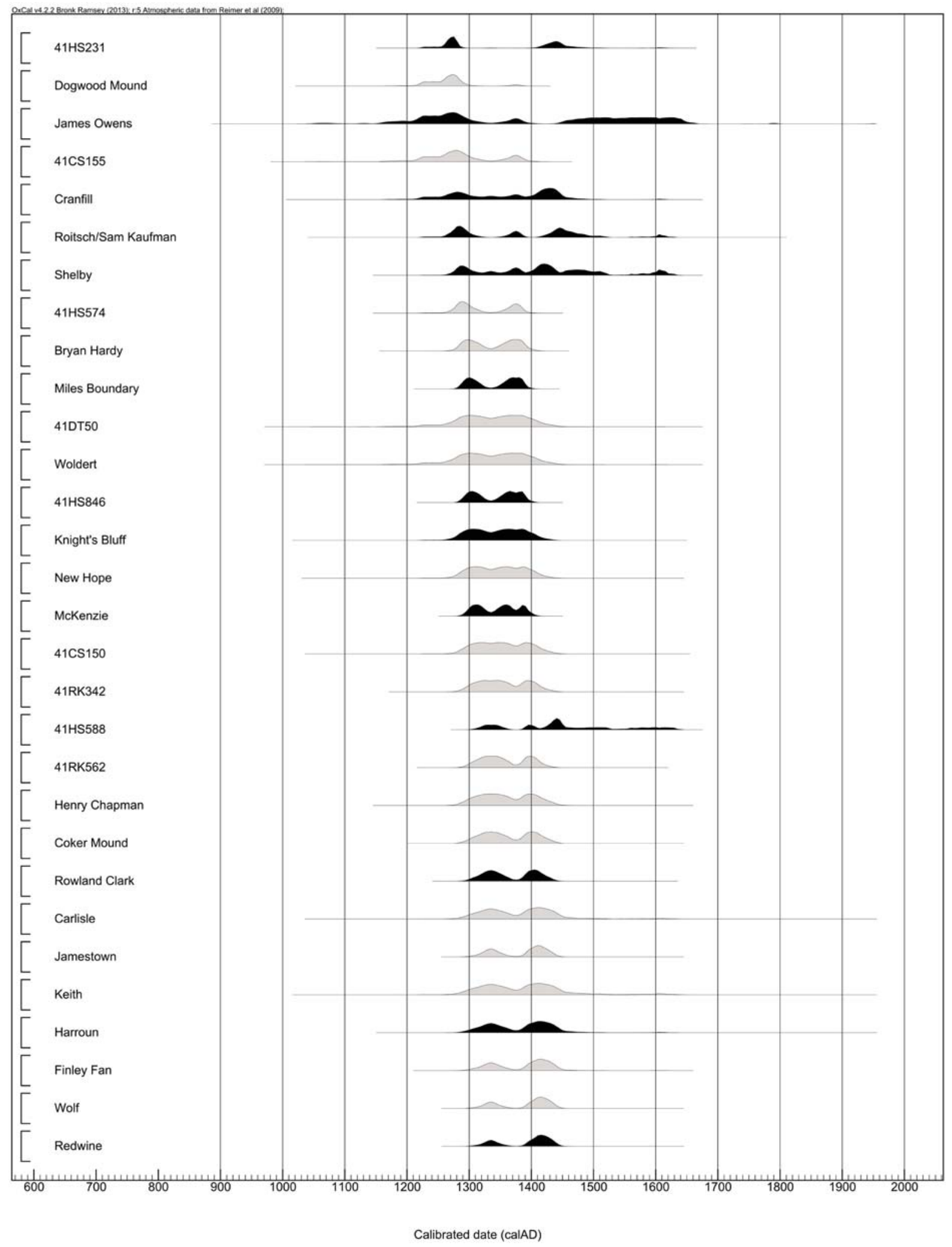

Figure 2c. Site-specific summed probability distributions listed in chronological order. Sites with combined dates appear in black, post-A.D. 1150. 


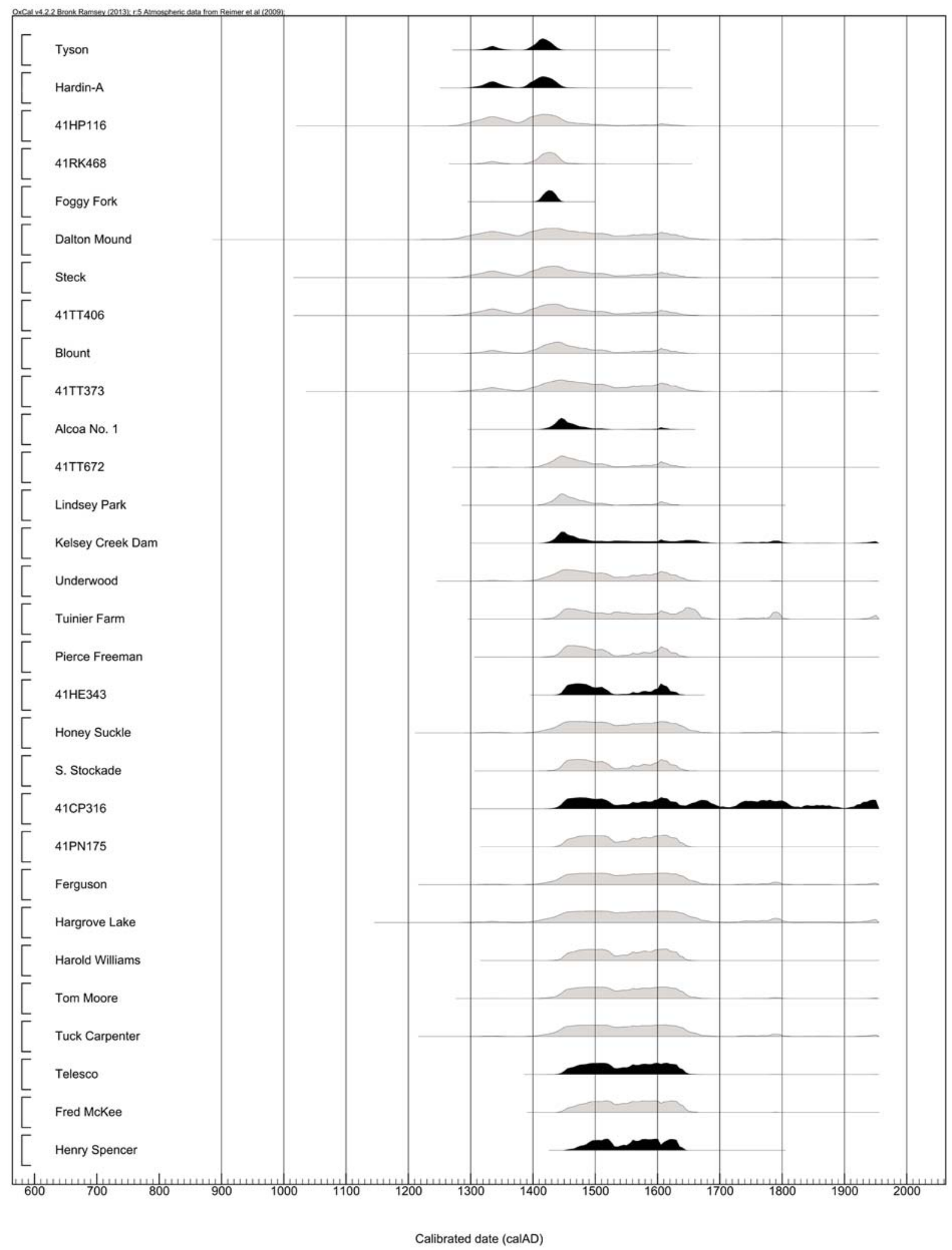

Figure 2d. Site-specific summed probability distributions listed in chronological order. Sites with combined dates appear in black, post-A.D. 1300. 


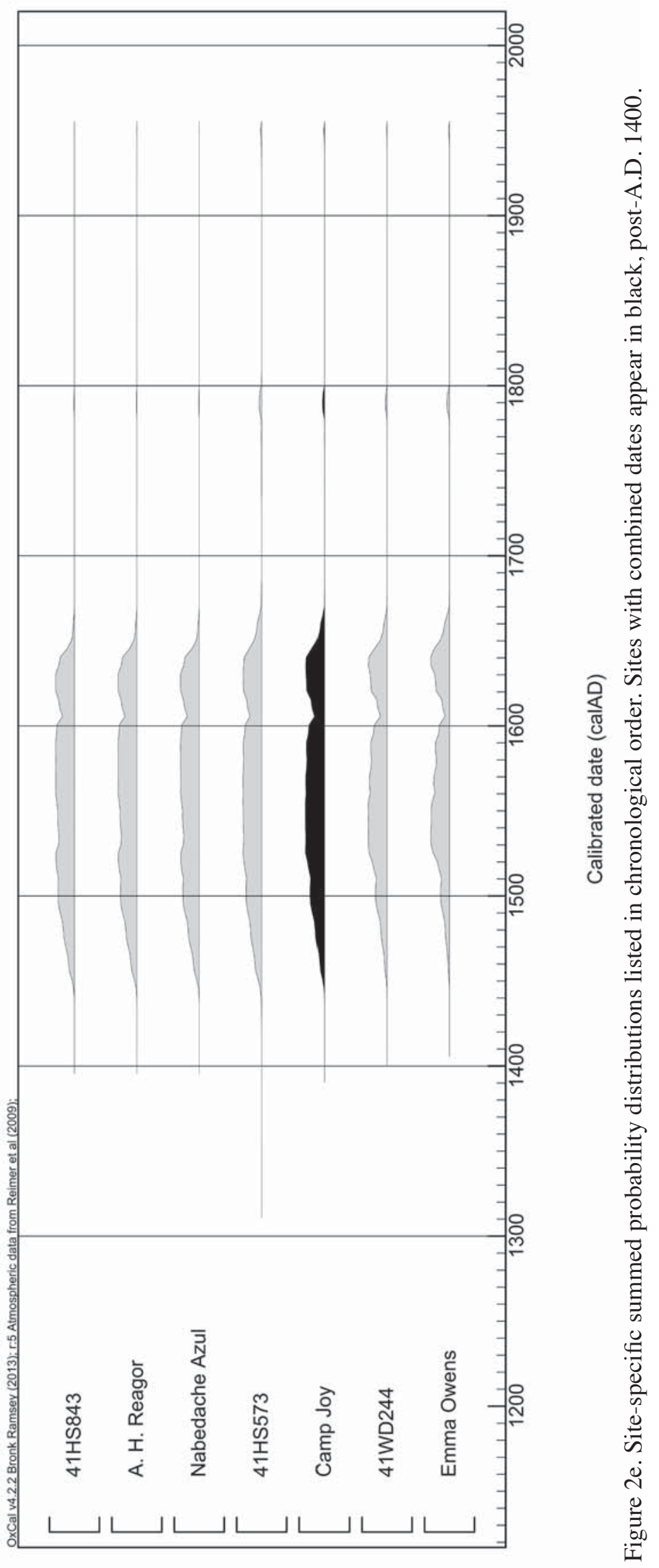




\section{CONCLUSIONS}

The date combination process, when paired with summed probability distributions, allows for in the establishment of more accurate and precise temporal ranges for Caddo archaeological sites in East Texas; in this case, 55 important sites with nine or fewer ${ }^{14} \mathrm{C}$ samples. This method can be used to explore the temporal range of sites, and their combination serves as a means of highlighting the various temporal trends within almost a 900 year portion of the Caddo archaeological tradition (ca. A.D. 800-1680). The analysis of Caddo radiocarbon dates can help to identify and/or clarify the ages of features or events that appear to have occurred-potentially - within the same probabilistic span of time.

\section{REFERENCES CITED}

Bronk Ramsey, C.

2013 OxCal 4.1.7.Electronic resource, https://c14.arch.ox.ac.uk/login/login.php?Location=/oxcal/OxCal .html, accessed July 1, 2013.

Perttula T. K. and R. Z. Selden, Jr.

2011 East Texas Radiocarbon Database. Electronic resource, http://counciloftexasarcheologists.org/?page _id=27, accessed July 1, 2013

Reimer, P. J., M. G. L. Baillie, E. Bard, A. Bayliss, J. W. Beck, P. G. Blackwell, C. Bronk Ramsey, C. E.

Buck, G. S. Burr, R. L. Edwards, M. Friedrich, P. M. Grootes, T. P. Guilderson, I. Hajdas, T. J. Heaton, A.

G. Hogg, K. A. Hughen, K. F. Kaiser, B. Kromer, F. G. McCormac, S. W. Manning, R. W. Reimer, D. A.

Richards, J. R. Southon, S. Talamo, C. S. M. Turney, J. van der Plicht, and C. E.Weyhenmeyer

2009 IntCal09 and Marine09 radiocarbon age calibration curves, 0-50,000 years cal BP. Radiocarbon 51(4):1111-1150.

Selden Jr., R. Z.

2012 Modeling Regional Radiocarbon Trends: A Case Study from the East Texas Woodland Period. Radiocarbon 54(2):1-27.

2013a Consilience: Radiocarbon, Instrumental Neutron Activation Analysis and Litigation in the Ancestral Caddo Region. Ph.D. dissertation, Department of Anthropology, Texas A\&M University, College Station.

2013b A Preliminary Temporal Analysis of the East Texas Archaic. Journal of Northeast Texas Archaeology 42:55-69.

Selden Jr., R. Z. and T. K. Perttula

2013a Radiocarbon Trends and the East Texas Caddo Tradition (ca. A.D. 800-1680). Southeastern Archaeology 32(1):85-96.

2013b Temporal Dynamics of East Texas Caddo Sites with 10 or More Radiocarbon Dates. Journal of Northeast Texas Archaeology 41:81-99. 